\title{
Hubungan Politik dan Dakwah
}

\author{
Syamsul Bachri Day
}

\begin{abstract}
Nowadays, da'wah and politics were seen as two distinct areas. Such opinion proved to be disadvantage because both politics and da'wah are essentially interrelating each other in a functional matter, even organics. In Islam, men are constituted as khalifah, or leader of the universe in order to manifest Allah's will. Equipped with religious principles, dynamic and creativity, along with ratio and amanah, it is the task of men to overcome every challenge. There are two kinds of politics in the world of Islam: high politics (high quality of politics) and low politics (low quality of politics). High politics covered some principles,

e.g.: politics as amanah, accountable, brotherhood. Meanwhile, low politics was characterized

by violence, brutality, meanness, total submission, and unethical political interactions all

of this remind us with Macchiavelian style of politics. Islam only addressed high politics in its practice for the good of society.
\end{abstract}

Kata kunci: politik, dakwah, high politics, low politics

\section{Pendahuluan}

Hubungan fungsional antara politik dan dakwah sering tidak dimengerti dengan baik oleh sementara kaum Muslimin sehingga banyak yang menganggap bahwa kegiatan politik berdiri sendiri, terpisah sama sekali dengan dakwah. Bahkan, dalam masyarakat kita ada kesan kurang positif terhadap kegiatan politik, seolah-olah politik mengandung kelicikan, hiprokasi, ambisi buta, penghianatan, penipuan, dan berbagai konotasi buruk lainnya.

Untuk menunjukkan bahwa kadangkala ada orang yang berpendirian politik tidak perlu dikaitkan sama sekali dengan moralitas agama, dapat saya berikan contoh kecil. Seorang politikus kiai-kiai politikus tentang kepindahannya dari suatu parpol ke porpol yang lainnya, dikatakan bahwa politik itu urusan kehidupan dunia dan jelas kehidupan dunia itu hanya main-main dan permainan saja. Jadi, kepindahannya dari satu parpol ke parpol lain hanyalah sekadar main-main. Malah kiai mengatakannya lagi dengan fasih, bukankah Tuhan sudah berfirman dalam Al-Quran :Tiadalah kehidupan dunia ini kecuali main-main dan permainan belaka? (wa ma hadzihil hayatuddunya illa lahwun wa la'ib).

Persepsi tentang politik seperti di atas, tentu cukup berbahaya. Ditinjau dari kacamata dakwah, pandangan politik semacam ini juga sangat merugikan. Oleh karena itu, pada tulisan ini penulis ingin mencoba melihat hubungan organik antara politik dan dakwah dalam pandangan Islam. Penulisan ini akan membahas arti dakwah, politik sebagai alat dakwah, dua jenis politik dan pentingnya profesionalisme politik dari tinjauan Islam. 
Mudah-mudahan penulisan ini akan menjadi jelas bagi kita bahwa kegiatan politik tidak perlu bertentangan dengan kegiatan dakwah. Sekaligus diharapkan dapat menghilangkan persepsi yang salah tentang politik dan juga tentang dakwah. Anggapan yang salah itu, misalnya, adalah bahwa politik itu bersifat memecah, sedangkan dakwah bertujuan merangkul sebanyak mungkin umat manusia, seolah ada perbedaan antara hakikat politik dan hakikat dakwah, sehingga berlaku ungkapan yang mengatakan "Idza daholat assiyasatu fi syaiin afsadathu” (bila politik sampai memasuki sesuatu bidang kehidupan tertentu, maka rusaklah bidang itu).

Secara etimologi, kata dakwah berasal dari bahasa Arab dalam bentuk masdar dari kata $d a^{\prime} a$ - yad'u. Secara harfiah, ia berarti panggilan, seruan, do'a, undangan, dan propaganda (Louis Makluf, 1975:216) dalam Subandi, (1994:10). Pengertian dakwah dari segi bahasa tersebut berarti juga menyeru, yaitu menyeru dengan satu tujuan untuk mendorong seseorang melaksanakan citacita tertentu.

Pengertian dakwah, menurut Endang Saifuddin Anshari dalam bukunya Wawasan Islam, memberikan pengertian dakwah dalam arti luas, yakni: "Penjabaran, penerjemahan dan pelaksanaan Islam dalam prikehidupan dan penghidupan manusia (termasuk di dalamnya: politik, ekonomi, sosial, pendidikan, ilmu pengetahuan, kesenian, kekeluargaan dll) dakwah dalam arti luas seluas kehidupan dan penghidupan itu sendiri (Anshari, 1985:159).

Dalam surat Yusuf:108, Allah mengajarkan pada Nabi Muhammad saw agar menyeru umat manusia ke jalan Allah. Dalam menyeru umat manusia ke jalan Allah itu Nabi beserta para pengikutnya bersandar pada keteranganketerangan yang jelas (bashirah) dan sambil memuji kesucian Allah, Nabi menjelaskan bahwa beliau bukan tergolong orang-orang musyrik. Dakwah dalam ayat ini adalah "ad-dakwah ila Allah" (ad'u ila Allah), yaitu seruan, ajakan, panggilan, dan imbauan kepada Allah. Kembali kepada Allah.

Dalam surat Fushilat:33, Allah menegaskan bahwa tidak ada perkataan yang lebih baik daripada menyeru kepada Allah dan melakukan amal soleh serta menyatakan diri sebagai orang Islam, orang yang berserah diri kepada Allah. Dalam ayat ini pun dakwah itu berarti "dakwah ila Allah". Demikian pula seorang Muslim seharusnya dengan jelas identitasnya sebagai Muslim, agar tidak dijumbuhkan seorang musyrik. Hal ini perlu karena politeis (musyrikun) juga berusaha mengembangkan 'dakwahnya'.

Kedua ayat di atas, Quran secara imperatif menyuruh setiap Muslim untuk menyeru umat manusia ke jalan Tuhan dengan bijaksana, nasihat yang baik, dan argumentasi yang jitu. Ayat 125 dari surat An-Nahl ini menunjukkan pada kita caracara yang baik untuk mengajak hamba-hamba Allah ke jalan-Nya dan tidak ada sedikit pun konotasi bahwa 'dakwah ila Allah' atau 'dakwah ila sabilillah' dianjurkan lewat paksaan, apalagi kekerasan. Dari ayat Al-Quran ini kita mengetahui bahwa setiap Muslim pada hakikatnya berkewajiban melakukan dakwah supaya kebenaran agama yang telah ia terima dapat dinikmati orang lain. Untuk meminjam istilah Ismail Al-Faruqi, kebenaran Islam bukan saja bersifat teoretik, melainkan juga bersifat aksiologis dan praktis. Kebenaran inilah yang harus ditularkan seluas-luasnya kepada masyarakat manusia lewat sikap dan pandangan yang bijak, nasihat yang indah, dan argumen yang kokoh.

Jika kita berpegang pada pandangan Qur'an maka diciptakannya manusia di muka bumi ini adalah untuk menjadi khalifah Allah atau makhluk Tuhan, yang bertugas mengelola kehidupan dunia sesuai dengan kehendak Tuhan. Manusia Muslim mempunyai peranan yang dinamik dan kreatifuntuk mengemban tugas kekhilafahan tersebut. Dibekali dengan agama, rasio, dan amanah (free will), ia diharapkan mampu untuk memecahkan masalahmasalah yang ia hadapi dengan menjadikan Quran dan Sunnah sebagai paradigma, atau katakanlah, 'term of reference-nya'. Dalam tugas kekhalifahan itu dakwah menjadi bagian yang paling esensial, karena pembangunan manusia dan masyarakat sebagai dikehendaki Allah Sang Maha Pencipta (al-Khaliq) hanya dapat terselenggarakan jika 
secara individual dan secara kolektif, manusia dan masyarakat bersedia menyambut 'dakwah ila Allah' dan menebarkan amal soleh (setiap usaha, kerja dan tindakan yang bernilai kebajikan) ke tengah masyarakat.

'Dakwah ila Allah' atau ajakan ke jalan Allah selalu ditekankan dan menjadi substansi pokok tugas seorang Muslim. Hal ini sangat jelas, untuk membedakan 'dakwa ila an-nar' atau ajakan masuk neraka yang menjadi pekerjaan orang-orang musyrik (lihat QS-Surat Al-Baqarah:221). Dakwah yang berisikan amar ma'ruf dan nahyi munkar yang digerakkan oleh orang-orang Muslim (QS alImran:104) dalam kenyataanya memang berhadaphadapan dengan amar ma'ruf yang dilakukan oleh orang-orang munafik(QS. at-Taubah:67). Gerakan dakwah yang berlawanan inilah yang pada hakikatnya menjadi kehidupan dunia cukup menarik. Konfrontasi antara yang ma'ruf dan yang munkar, antara dakwah yang mengajak manusia agar menjadi ashabul yamin dan yang mendorong manusia supaya menjadi ashabul syimal, antara calon-calon ashabun nar memang membuat kehidupan umat manusia penuh dengan perjuangan, pergulatan, dan pertentangan.

Kegiatan dakwah Islam, sesungguhnya meliputi semua dimensi kehidupan manusia, berhubung amar ma'ruf dan nahyi munkar, juga meliputi seluruh kegiatan kehidupan. Akan tetapi, jangan dilupakan bahwa para pendukung amar munkar dan nahyi ma'ruf juga menggunakan setiap jalur kegiatan kehidupan. Dengan demikian, kegiatan budaya, politik, ekonomi, sosial, dll, dapat dijadikan kegiatan dakwah; baik dakwah Islamiyah (dakwah ila Allah) maupun dakwah jahiliyah, yakni dakwah yang menjadikan neraka sebagai muara akhir (dakwah ila an-nar).

Dari pemahaman seperti ini mudah kita mengerti bahwa politik pada hakikatnya menjadi bagian dari dakwah. Dakwah Islam adalah setiap usaha rekonstruksi masyarakat yang masih mengandung unsur-unsur jahili menjadi masyarakat yang islami. Dakwah Islam (selanjutnya kita singkat dakwah), oleh karenanya juga berarti Islamisasi seluruh kehidupan manusia.

Hamka (1984:9) menjelaskan ayat 104 dari surat
Al-Imran, dengan menyebutkan, ada dua bidang untuk menyampaikan dakwah, umum dan khusus. Secara umum, ia termasuk propaganda menjelaskan kemurnian agama keluar. Ia bersifat mengajak orang lain supaya turut memahami hikmat ajaran Islam. Dan terkadang bersifat menangkis serangan atau tuduhan terhadap agama. Model propaganda seperti ini memerlukan keterampilan pengetahuan yang mapan, sebab ia akan berhadapan dengan paham lain, yang juga memiliki etika penyebarannya sendiri.

Sedangkan secara khusus, dakwah dalam kalangan keluarga sendiri, menimbulkan suasana agama di kalangan keluarga, mendidik agar patuh akan perintah Tuhan berlomba berbuat baik. Dakwah tidak berhenti walaupun antarsesama golongan sendiri dan meskipun penghuni dunia ini telah menyatakan dirinya sebagai Muslim.

Menurut Mohammad Al-Naquib Al-Attas yang dikutip A. Rais (2000:13) dalam buku Ijtihad politik menyebutkan, islamisasi adalah proses pembebasan manusia, pertama-tama dari segenap tradisi yang bersifat magis, mitologis, animistis dan tradisi budaya-nasional irrasional; kemudian juga berarti pembebasan manusia dari pengaruh sekular yang membelenggu pemikiran dan tingkah lakunya.

Tauhid sebagai poros (axis) seluruh ajaran Islam menggerakkan kegiatan dakwah untuk membebaskan manusia dari perangkap-perangkap nativisme, yang mengajak orang kembali kepada ajaran-ajaran nenek-moyang walaupun ajaranajaran tersebut bersifat irasional, animistis, dll. Di pihak lain, dakwah juga menyelamatkan manusia dari kungkungan sekularisme yang cenderung menuhankan manusia perlahan-lahan, mencoba menggusur nilai-nilai yang sepenuhnya humanistik. Humanisme sekularis, mempunyai kredo khusus yaitu: 'man is the measure of all things,

Dari pemahaman dakwah seperti ini tampak makin jelas bahwa dakwah memang berwatak progresif, bahkan revolusioner. Dakwah tidak akan menerima status quo yang bertentangan dengan tuntutanan wahyu atau ajaran-ajaran agama. Dakwah adalah gerakan dalam berbagai bidang kehidupan secara simultan untuk mengubah status 
quo, agar nilai-nilai Islam memperoleh kesempatan untuk tumbuh subur, demi kebahagiaan seluruh umat manusia. Perubahan itu sendiri dapat bersifat reformatifatau revolusioner, tergantung pada situasi sosial, politik, ekonomi, dan situasi mentalpsikologik suatu masyarakat. Untuk masyarakat Indonesia, perubahan reduktif, sehingga kegiatan dakwah di bidang apapun harus dirancang sesuai dengan kondisi masyarakat Indonesia.

Tauhid sebagai ruh dakwah mendorong rekonstruksi sosial yang sesuai dengan ajaranajaran Allah. Dengan perkataan lain, dakwah yang bersendikan tauhid senantiasa berusaha memasyarakatkan Islam sebagai agama, sebagai pandangan hidup, dan sebagai paradigma pemecahan setiap masalah yang timbul dalam masyarakat modern dengan segala macam manifestasinya, dengan segala pencabangan dan perinciannya. Ajakan tauhid ini ditujukan kepada seluruh umat manusia, agar mereka melakukan transformasi sosio-ekonomi dan sosio-politik, menuju suatu orde yang Islami. Namun, ajakan tauhid bersifat sukarela. Jawaban terhadap ajakan tauhid sepenuhnya tergantung pada manusia sendiri, apakah mereka mau beriman ataukah kufur (ingkar), sesuai dengan firman Allah (QS. al-Kahfi: 29), "Dan katakanlah, kebenaran itu datang dari Tuhanmu. Maka barangsiapa mau bolehlah ia beriman, dan barangsiapa mau boleh ia tidak percaya (kufur)".

Sementara itu, timbul pertanyaan mengapa 'dakwah ila Allah' atau 'dakwah ila al-khair' diwajibkan oleh Islam? Jawaban singkatnya adalah bahwa dakwah diperlukan karena manusia tidak pernah dapat mengandalkan nasibnya hanya pada akalnya dan pada nafsunya. Akal manusia dapat menyeleweng dari kebenaran dan bersifat nisbi, sementara nafsu manusia cenderung destruktif. Manusia memerlukan wahyu ilahi, membutuhkan bimbingan Tuhan (divine guidance) dalam memecahkan masalah-masalah kehidupan.

\section{Politik sebagai Alat Dakwah}

Sebagaimana di jelaskan di atas bahwa dakwah adalah rekonstruksi masyarakat sesuai ajaran Islam. Semua bidang kehidupan dapat dijadikan arena dakwah dan seluruh kegiatan hidup manusia dapat digunakan sebagai sarana alat dakwah. Kegiatan politik, sebagaimana halnya dengan kegiatan ekonomi, usaha-usaha sosial, gerakan-gerakan budaya, kegiatan-kegiatan iptek, kreasi seni serta kodifikasi hukum dll, seharusnya memang menjadi alat dakwah bagi seorang Muslim.

Politik dapat didefinisikan dengan berbagai cara, akan tetapi bagaimana pun didefinisikan satu hal yang pasti, yaitu politik menyangkut kekuasaan dan cara penggunaan kekuasaan. Di samping itu, dalam pengertian sehari-hari, politik juga berhubungan dengan cara dan proses pengelolaan pemerintahan satu negara. Oleh karena itu, kegiatan politik merupakan salah satu kegiatan hidup yang cukup penting, mengingat suatu masyarakat hanya bisa hidup teratur kalau masyarakat tersebut hidup dan tinggal dalam sebuah negara dengan segala perangkat kekuasaannya. Demikian pentingnya peranan politik dalam masyarakat moderen, sehingga banyak orang berpendapat bahwa politik adalah panglima. Artinya, politik sangat menentukan corak sosial, ekonomi, politik, budaya, hukum, dan berbagai aspek kehidupan lainnya.

Bagi setiap Muslim, kegiatan politik juga harus menjadi bagian integral dari kehidupannya yang utuh. Tidak benar seorang Muslim menjauhi, apalagi membenci kegiatan tertentu yang menentukan arah kehidupan dan nasibnya. Misalnya, menjauhi kehidupan ekonomi atau kehidupan politik. Kehidupan dunia harus 'direbut' dan dikendalikan sesuai dengan ajaran-ajaran Tuhan. Nabi Muhammad sendiri hanya menjelang kenabiannya saja berkontemplasi di goa Khira, tetapi kemudian terjun ke arena kegiatan dunia sampai akhir hayatnya. Beliau tidak pernah sekalipun surut dan kembali lagi ke goa Khira. Ini menunjukkan bahwa kaum Muslimin, sebagai pengikut Nabi, juga harus memperhatikan nasibnya di dunia. Bahkan hanya di dunia ini sajalah kita punya kesempatan untuk menunaikan tugas sebagai khalifah Allah. Tidak seyogianya kaum Muslimin menyerahkan urusan dunianya atau nasibnya kepada orang lain.

Oleh karena politik adalah alat dakwah maka aturan permainan yang harus ditaati juga harus 
paralel dengan aturan permainan dakwah. Misalnya, tidak boleh menggunakan kekerasan atau paksaan, tidak boleh menyesatkan, tidak boleh menjungkirbalikkan kebenaran dan juga tidak tidak diperkenankan adanya penggunaan-penggunaan induksi-induksi psikotropik yang mengelabui masyarakat. Di samping itu, keterbukaan, kejujuran, rasa tanggung jawab, serta keberanian menyatakan "yang benar adalah benar dan yang batil adalah batil" harus menjadi ciri-ciri politik yang berfungsi sebagai sarana dakwah.

Politik yang memiliki ciri-ciri di atas sudah tentu fungsional terhadap tujuan utama dakwah. Sebaliknya, bila aturan permainan yang digunakan dalam politik tidak paralel dengan aturan permainan dakwah pada umumnya, maka mudah diperkirakan bahwa politik semacam itu disfungsional terhadap dakwah. Akan tetapi, jangan dilupakan bahwa aturan-aturan permainan itu sesungguhnya hanyalah refleksi dari moralitas dan etika yang lebih dalam. Moralitas dan etika kegiatan dakwah dalam bidang apa pun harus bersumber pada tauhid, sehingga moral dan etika para politisi Islam juga harus bersandar pada tauhid. Bila moral dan etik yang tauhidi dilepaskan dari politik hal itu akan berjalan tanpa arah dan bermuara pada kesengsaraan orang banyak.

Politik yang fungsional terhadap tujuan dakwah adalah politik yang sepenuhnya mengindahkan nilai-nilai Islam. Dalam hubungan ini perlu diperhatikan bahwa kehidupan politik yang Islami tidak memberikan tempat bagi sekularisasi, walaupun sementara orang sekularisasi dianggap sebagai sebagai proses yang tidak bisa tidak membarengi modernisasi.

Menurut Harvey Cox, komponen-komponen integral sekularisasi adalah 'disenchantment of nature', berarti desakralisasi politik dan dekonsekrasi nilai-nilai.

'Disenchantment of nature' berarti pembebasan alam dari nilai-nilai agama agar masyarakat dapat dengan bebas melakukan perubahan dan pembangunan. Desakralisasi politik bermakna penghapusan legitimasi sakral atas otoritas dan kekuasaan yang merupakan syarat untuk mempermudah berlangsungnya perubahan sosial dan politik dalam proses sejarah. Sedangkan yang dimaksud dengan dengan dekonsekrasi nilainilai adalah merelativisasikan setiap sistem nilai termasuk nilai-nilai agama, supaya manusia bebas mendorong perubahan-perubahan evolusioner tanpa terikat lagi dengan nilai-nilai agama yang bersifat 'ultimate' atau absolut.

Sekali pun sekularisasi dicoba dibedakan dari sekularisme, berhubung yang terakhir ini adalah ideologi sedangkan yang kedua menunjuk pada proses sosial yang bersifat 'openended', namun pada dasarnya ia juga sebuah ideologi, yakni ideologi sekularisasionisme (secularizationisme). Politik yang menganut sekularisasionisme sudah tentu menjadi politik tanpa dasar-dasar moral keagamaan dan nilai-nilai yang berlaku di dalamnya bersifat sangat relatif dan situasional. Politik semacam ini secara potensi maupun aktual akan sering bertabrakan dengan tujuan dakwah.

Politik yang dijalankan oleh seorang Muslim dan yang berfungsi sebagai alat dakwah, sudah tentu bukan politik sekular, akan tetapi politik yang penuh dengan komitmen kepada Allah. Tujuan yang diletakkan oleh politik semacam ini bukanlah kekuasaan demi kekuasaan atau tercapainya suatu kepentingan demi pemenuhan kepentingan itu sendiri. Kekuasaan, pengaruh, kepentingankepentingan tertentu, posisi politik, dsb. bukanlah tujuan, tetapi sarana atau tujuan antara untuk mencapai tujuan yang sesungguhnya, yaitu pengabdian kepada Allah. Hal ini sesuai dengan ikrar seorang Muslim bahwa shalatnya, ibadahnya, hidup dan matinya, diabdikan hanya kepada Allah semata (surat al-Annam ayat 162).

Ayat ini juga jelas menolak sekularisasi, karena sekularisasi pada dasarnya melakukan kompartementalisasi kehidupan, yakni antara kompartementalisasi kehidupan duniawi dan kompartementalisasi ukhrowi. Padahal, seluruh kehidupan adalah satu Yang ukhrowi adalah kelanjutan belaka dari yang duniawi, sesuai hadits Nabi: "ad-dunya mazro'atul akhirah" (dunia adalah sawah ladangnya akhirat). Artinya apa yang kita lakukan di dunia dalam bidang apa pun, akan kita petik hasilnya besok di akhirat. Itulah sebabnya, seluruh kegiatan dalam berbagai dimensi 
kehidupan seorang muslim diabdikan kepada Allah swt.

Politik sebagai alat dakwah, oleh karena itu, harus menunjang rekonstruksi masyarakat berdasarkan ajaran-ajaran Islam. Rekonstruksi masyarakat itu dapat dilakukan dalam bidang ekonomi, sosial, budaya, iptek dan sudah tentu juga dalam bidang politik. Pengelolaan tugas-tugas kenegaraan di bidang legislatif, eksekutif, yudikatif, dan dalam masyarakat luas harus bersendikan pada tauhid dan diwarnai dengan spirit 'dakwah ila Allah'.

\section{Dua Jenis Politik}

George Catlin memberi definisi politik sebagai 'the act of human or social control'. Harold Lasswell memberikan pengertian bahwa politik menyangkut 'who gets, what, when, how'. What di sini terutama berupa kekuasaan atau otoritas politik, sedangkan siapa, kapan, dan bagaimana adalah masalah-masalah yang menentukan bentuk pengelolaan politik suatu masyarakat. (Uchyana:1992)

Politik kepartaian, rekrutmen pejabat atau pegawai, proses agregasi dan artikulasi kepentingan, proses pemecahan konflik kepentingan antargolongan dalam masyarakat, proses pembuatan keputusan dalam politik domestik, maupun luar negeri dan lain sebagainya, adalah contoh-contoh kegiatan politik yang tidak dapat dilepaskan dari fondasi etika dan moral yang dianut. Bagi seorang Marxis, suatu tindakan politik dianggap baik bila tindakan itu menguntungkan kaum ploletar, memperlemah posisi dari apa yang mereka namakan kelas borjuis dan menuju revolusi sosial ke arah masyarakat tanpa kelas.

Bagi seorang sekularis-pragmatis, suatu tindakan politik adalah baik bila mendapat 'benefit' atau keuntungan praktis dan manfaat materil, walaupun berdasarkan pertimbanganpertimbangan sesaat. Sedangkan bagi seorang Muslim suatu tindakan politik adalah baik bila tindakan tersebut berguna bagi seluruh rakyat sesuai dengan ajaran 'rahmatan lil alamien'.

Secara demikian dari tinjauan Islam ada dua jenis politik, yaitu politik kualitas tinggi (high politic) dan politik kualitas rendahan (low politic).

Ada 3 ciri yang harus dimiliki politik berkualitas tinggi atau oleh mereka yang menginginkan terselenggaranya 'high politics' (Rais, 1987:61).

Pertama, setiap jabatan politik pada hakikatnya berupa amanah (trust) dari masyarakat yang harus dipelihara sebaik-baiknya. Amanah ini tidak boleh disalahgunakan. Misalnya untuk memperkaya diri atau menguntungkan hanya golongan sendiri dan menterlantarkan kepentingan umum. Kekuasaan harus dilihat sebagai nikmat yang dikaruniakan Allah untuk mengayomi masyarakat, menegakkan keadilan, dan memelihara orde atau tertib sosial yang egaliterian. Kekuasaan, betapapun kecilnya, harus dimanfatakan untuk membangun kesejahteraan bersama, sesuai yang telah diamanatkan atau 'message' yang telah dipercayakan oleh masyarakat luas. Seseorang yang duduk di lembaga eksekutif, legislatif, yudisial atau duduk dalam 'pressure group' yang berpengaruh atau memegang posisi kunci dalam suatu organisasi, sesungguhnya memiliki 'power' tertentu. Kekuasaan ini tidak boleh dipisahkan dari amanah yang harus terus mengarahkan penggunaan kekuasaan itu.

Kedua, setiap jabatan politik mengandung dalam dirinya mas'uliyyyah' pertanggungjawaban (accountability). Sebagaimana diajarkan oleh Nabi saw, setiap orang pada dasarnya adalah pemimpin yang harus mempertanggungjawabkan kepemimpinannya atau tugas-tugasnya. Kesadaran akan tanggung jawab ini sangat menentukan dalam usaha kita menyelenggarakan politik yang berkualitas tinggi. Akan tetapi, tanggung jawab ini bukan terbatas di hadapan institusi-institusi atau kelembagaan yang bersangkutan, lebih penting lagi adalah tanggung jawab di hadapan Allah, di hadapan mahkamah yang paling adil esok di akhirat. Seorang politikus atau pejabat atau negarawan, yang kesadaran tanggungjawabnya pada Tuhan sangat dalam, secara otomatis memiliki 'built-in control' yang tida ada taranya. Ia mempunyai kendali diri (selfrestraint) yang sangat kuat untuk tidak terperosok ke dalam rawa-rawa kemunafikan. 
Ketiga, kegiatan politik harus dikaitkan secara ketat dengan prinsip ukhuwwah (brotherhood), yakni persaudaraan di antara sesama umat manusia. Ukhuwwah dalam arti luas melampaui batas-batas etnik, rasial, agama, latar belakang sosial, keturunan, dan lain sebagainya. Masalahnya, setiap orang, terlepas dari latar belakang manapun ia datang, jika dipukul pasti sakit, jika tidak makan pasti lapar, dan seterusnya. Oleh karena itu, perbuatan politik yang berkualitas tinggi akan menghindari gaya politik konfrontatif yang penuh dengan konflik dan melihat pihak lain sebagai pihak yang harus dieliminasi. Sebaliknya, gaya politik yang diambil adalah yang penuh dengan $u k h u w w a h$, mencari saling pengertian dan membangun kerjasama keduniaan seoptimal mungkin dalam menunaikan tugas-tugas kekhilafahan.

'High politics' dengan ciri-ciri minimal seperti tersebut di atas sangat kondusif bagi pelaksanaan amar ma'ruf nahyi munkar. Barangkali inilah yang dimaksud dengan Qur'an surat al-Hajj, ayat 41, "Mereka adalah orang-orang yang bila Kami beri kekuasaan yang teguh di muka bumi niscaya menegakkan shalat dan membayar zakat dan menyuruh (manusia) berbuat kebaikan serta mencegah kejahatan;dan bagi Allah sajalah kembalinya segala macam urusan".

High politics dalam kenyataan memang terasa sangat ideal, tidak saja di negara-negara berkembang, tetapi bahkan di negara-negara maju. Bahkan, di Amerika, di negara yang merupakan jagonya demokrasi, politik kualitas tinggi merupakan barang yang sangat mewah dan langka.

Di negara berkembang, bahkan di negerinegeri Muslim, politik berkualitas rendahan pada umumnya justru dominan. Ditinjau dari sudut pandang Islam, politik semacam ini tidak mendukung maksud-maksud dakwah, tetapi justru menjegal dakwah, merusak rekonstruksi masyarakat yang Islami.

Dalam pembicaraan sehari-hari, kita sering mendengar istilah politik Machiavellis dengan konotasi otomatis sebagai politik yang tidak sehat, penuh hiprokrisi, kelicikan, dan sebagainya. Dalam pembahasan akademik, Machiavelli itu sendiri merupakan tokoh yang kontroversial. Namun, ajaran-ajaran politiknya yang terkandung dalam bukunya The Prince memang tidak mencerminkan 'high politics'. Dan dari kaca mata dakwah jelas destruktif, setidak-tidaknya counter-productive. Di sini akan dilihat sekilas tentang gagasangagasannya yang dimuat dalam bukunya yang terkenal itu. Dan merupakan kualitas 'low politic', meminjam istilah A. Rais (Panjimas : No. 532)

Pertama, Machiavelli mengajarkan bahwa kekerasan (violance) brutalitas dan kekejaman merupakan cara-cara yang sering kali perlu diambil oleh penguasa. Baginya, kekerasan, brutalitas dan kekejaman dapat digunakan kapan saja asal tujuan yang dikejar dapat tercapai. Karena itu, terkenal semboyan: tujuan menghalalkan segala cara. Pandangan seperti ini mendorong manusia bergerak dalam bidang politik menjadi "coldblooded", alias berdarah dingin. Melangkahi mayat orang lain untuk mencapai tujuan sendiri dianggap sebagai suatu hal yang wajar-wajar saja. Kekuasaan sebagai amanah dan nikmat dari Tuhan yang harus dipergunakan sebaik-baiknya tidak dikenal sama sekali dalam ajaran ini.

Kedua, penaklukan secara total atas musuhmusuh politik dinilai sebagai kebijakan puncak (summun bonum). Musuh tidak boleh diberi kesempatan untuk bangkit dan kalau perlu diperlakukan sebagai barang, bukan sebagai manusia. Politik berintikan pada perjuangan untuk merebut kekuasaan (struggle for power), dan instabilitas pemerintahan biasanya disebabkan oleh nafsu kuasa manusia yang tidak mengenal batas (the limitless human appetite for power). Oleh sebab itu, bagi orang yang sedang berkuasa, kata Machiavelli, operasi dan supresi, atau penindasan dan penekanan, serta penaklukan adalah kebijakan puncak (summun bonum). Di sini konsep $u k h u w w a h$ atau persaudaraan di antara umat manusia tidak sedikit pun terlintas dalam benak Machiavelli.

Ketiga, dalam menjalankan kehidupan politik seorang penguasa harus dapat bermain seperti binatang buas, terutama seperti singa dan sekaligus anjing pemburu. Kebuasan singa akan menakutkan serigala, sementara kecerdikan dan 
kelicikan anjing pemburu dapat menghindari jebakan-jebakan. Seorang penguasa harus dapat menjadi anjing pemburu untuk mengenali berbagai perangkap dan dapat menjadi singa untuk menggertak manusia-manusia serigala. Mereka yang bertingkah seperti singa saja tidak akan waspada. Orang yang dapat berperan seperti anjing pemburu akan menjadi pemain politik terbaik, tetapi ia harus tahu bagaimana bersikap seperti musang berbulu ayam. Pada umumnya, manusia berpikir sangat bersahaja dan menyerah kepada kebutuhan-kebutuhan mendesak sehingga seorang penguasa yang suka menipu pasti akan menemukan orang-orang yang membiarkan dirinya untuk ditipu.

Kendati pun wejangan-wejangan Machiavelli ini ditujukan kepada sang pangeran sebagai penguasa, tetapi banyak sekali politisi yang menimba ajaran-ajaran Machiavelli tadi dan mempraktikkannya dalam kehidupan politik.

Low politic gaya Machiavelli ini mudah diserap karena naluri-naluri dan nafsu rendah manusia ditampung secara luas. Barangkali tidak perlu kita jelaskan lebih jauh bahwa jenis politik ini tidak akan pernah berjalan paralel dengan tujuan dakwah.

\section{Profesionalisme Politik}

Setelah diuraikan di aas secara singkat tentang dua jenis politik dan hubungan fungsional antara high politics dan dakwah dalam arti luas, maka perlu kiranya kaum Muslimin mengembangkan profesionalisme politik yang tipikal Islam.

Di zaman moderen sekarang, bidang politik memang harus diterjuni secara profesional dan tidak seyogianya dimasuki secara amatiran. Akan tetapi, profesi politik yang dimaksud di sini bukan seperti dimengerti oleh sementara orang bahwa menipu adalah 'tugas' pokok kaum politisi. Misalnya ada sarjana yang berpendapat, "berhubung kaum politisi dianggap sebagai kejahatan yang perlu, baik tingkah laku maupun eksistensi mereka, sebaiknya dimaafkan saja. Kiranya dapat diterima akal bila demi tuntutan profesinya, seorang serdadu harus membunuh dan seorang politikus harus menipu". Keharusan menipu dalam profesi politik bukanlah apa yang kita maksudkan.

Yang jelas, perkembangan zaman telah menuntut spesialisasi dan pembagian tugas dalam kehidupan masyarakat modern. Politik, sebagai salah satu bidang kegiatan hidup yang berhubungan dengan masalah-masalah pemerintahan dan kenegaraan serta proses pembuatan keputusan dalam berbagai kebijakan di tingkat nasional, regional, dan lokal, dewasa ini memerlukan pengetahuan dan keahlian tersendiri. Karena itu, tidak sembarang orang misalnya dapat menjadi eksekutif atau memegang jabatan-jabatan politik lainnya.

Di kalangan umat, harus ditumbuhkan kaderkader politik yang tangguh beraqidah dan menguasai persoalan-persoalan politik serta kaitannya dengan persoalan-persoalan sosial, ekonomi, budaya, psikologi, dan lain sebagainya. Masalah-masalah politik tidak dapat di garap sambil lalu dan tanpa pengetahuan yang cukup. Jangan sampai yang terjun ke gelanggang politik adalah mereka yang tanpa bekal pengetahuan dan pemahaman Islam secara benar. Bila wawasan Islam dan cakrawala pengetahuan politik dan kemasyarakatan sangat sempit, bukan mustahil timbul keanehan-keanehan. Misalnya, tokoh-tokoh di kalangan umat bersitegang, bahkan berkonfrontasi satu sama lain hanya sebuah kursi di parlemen. Atau, tuduh menuduh dan perang terbuka di media massa. Bahkan, tidak jarang fitnah dijadikan alat berpolitik, sementara fitnah itu sendiri, menurut Quran, secara moral lebih bahaya alias gawat daripada pembunuhan.

Low politics seperti ini dapat terjadi di kalangan umat karena, antara lain, politik belum didekati secara profesional dan kebanyakan pelaku politik barangkali saja belum bersedia menggunakan moralitas dan etika Quran secara konsekuen. Di samping situasi umum memang mencerminkan berlakunya low politics di atas, sehingga lebih mudah berenang menuruti arus dari pada melawan arus. Untuk mengatasi amateurisme politik itulah diperlukan pengembangan profesionalisme politik di kalangan umat, agar muncul kader-kader politik yang 
beraqidah, berpengetahuan luas, punya integritas, dan memahami dengan baik kaitan fungsional antara politik dan dakwah. Bila umat secara keseluruhan sudah mampu memainkan high politics, rekonstruksi masyarakat Islam insya Allah akan banyak tertolong. Politik di zaman modern menuntut wawasan, dan kecakapan. Nabi sendiri mengajarkan bahwa kita harus menyerahkan masing-masing urusan kepada para ahlinya, jika kita tidak ingin melihat kehancuran.

\section{Penutup}

Bagi sebagian orang, barangkali apa yang di paparkan di atas terlalu ideal, bahkan utopis. Akan tetapi, apabila kita ingin memperbaiki keadaan, maka gambaran ideal tentang keadaan itu harus kita paparkan agar menjadi jelas ke mana kita harus pergi. Begitu pula bila kita bicara antara hubungan dakwah dengan politik. Hanya politik kualitas tinggi saja yang dapat berjalan paralel dan harmonis dengan tujuan besar dakwah. Politik kualitas tinggi inilah yang dikehendaki ajaranajaran Islam. Bila dihadapkan dengan kenyataan yang berlangsung di mana low politics merajalela di tengah masyarakat, kita lantas menghadapi berbagai masalah yang dilematis. Memainkan politik kualitas tinggi di tengah samudra politik kualitas rendahan, memang tidak gampang. Lebih sulit lagi merelevansikan politik dengan tujuan dakwah agar hubungan fungsional, bahkan hubungan organik di antara keduanya dapat berjalan mulus. Namun di sinilah justru terletak tantangan kita bersama.
Mudah-mudahan tulisan ini akan menjadi jelas bahwa kegiatan politik tidak perlu bertentangan dengan kegiatan dakwah. Sekaligus diharapkan dapat menghilangkan persepsi yang salah tentang politik dan juga tentang dakwah. Anggapan yang salah itu, misalnya, adalah bahwa politik itu bersifat memecah, sedangkan dakwah bertujuan merangkul sebanyak mungkin umat manusia, sehingga seolah ada perbedaan antara hakekat politik dan hakekat dakwah.

\section{Daftar Pustaka}

A. Rais, Majalah Panji Masyarakat no. 529

A. Subandi, 1994, Ilmu Dakwah, Penerbit Yayasan Syahida Bandung.

Depag RI, 1998/1999, Islam untuk Disiplin Ilmu Hukum, Sosial, dan Politik, Direktorat Jendral Pembinaan Kelembagaan Agama Islam.

Fatwa, A.M. 2003, PAN Mengangkat Harkat dan Martabat Bangsa, Penerbit Institute for Transformation Studies) Jakarta.

Mahfud, M.,D. 1995, Serba Serbi tentang Hukum dan Politik, Pascasarjana Program Magister Ilmu Hukum, Universitas Islam Indonesia.

Najib, M. 2000, Ijtihad Politik, Serambi Ilmu Semesta, Jakarta.

Nimmo, Dan. 2000, Komunikasi Politik, Rosda Bandung. 
